\title{
THE STUDY OF REPRODUCTIVE BEHAVIOR AND EMBRYONIC DEVELOPMENTS OF NEOPOMACENTRUS CYANOMOS.
}

\author{
Kar-Hoe Loh ${ }^{1}$, You-Hua Cheng ${ }^{2,3}$ and Hong -Ming Chen*3,4 \\ ${ }^{1}$ Institute of Ocean and Earth Sciences, University of Malaya, 50603 Kuala Lumpur, Malaysia. \\ ${ }^{2}$ Department of Aquaculture, National Taiwan Ocean University, Keelung, Taiwan 202, R. O. C. \\ ${ }^{3}$ Fisheries Agency, Council of Agriculture, Executive Yuan, .2, Chaozhou St., Zhongzheng Dist., Taipei City \\ 100, R. O. C \\ ${ }^{4}$ Center of Excellence for the Oceans, National Taiwan Ocean University, Keelung, Taiwan 202, R. O. C. \\ Corresponding author:*hmchem@mail.ntou.edu.tw
}

\begin{abstract}
Regal demoiselle Neopomacentrus cyanomos belongs to the subfamily Pomacentrinae of family Pomacentridae. 50 individuals of this species were reared in laboratory aquaria to observe reproductive behaviors. Before courtship, the dominant male chose suitable substrate and cleared up it frequently. Among one reproductive affair, a male $N$. cyanomos mated with 3-4 females, and constantly moved outside of spawning substrate area to attract females, its black body color occur to grey stripes at that time. After spawning, the male protected fertilized eggs until hatching. During the 47 days of records dating from 21 June to 6 August 2004, the regal demoiselle ovulated five times, and mature female spawned once every 5 13 days ( $8 \pm 4$ days), each time produced about 3210 3560 eggs. These adhesion demersal eggs were trans- lucent and gourd form. Length of eggs was $1.27 \pm 0.06 \mathrm{~mm}(\mathrm{n}=66)$, egg diameter was $0.5 \pm 0.02 \mathrm{~mm}$, length of yolk-sac was $0.75 \pm 0.03 \mathrm{~mm}$ and maximum oil globule was $0.17 \pm 0.02 \mathrm{~mm}$. The developments of cleavage, morula, gastrula stage, and embryonic body were recorded. After 19.5 hours, optic vesicles and auditory vesicles were visible sequentially, and the embryo's somites turn obviously. After 35 hours, the embryo's head turned to the top position of egg. Through 84 hours, eyes turn blackish. After 108 hours, larvae broke the eggs and hatched out. The larval body length was $2.85 \pm 0.12 \mathrm{~mm}(\mathrm{n}=10)$.
\end{abstract}

(Keywords: Neopamacentrus cyanomos, reproductive behavior, embryonic development, larva)

\section{INTRODUCTION}

The damselfishes of the family Pomacentridae are one of the largest groups of reef fishes inhabiting tropical seas [1, 2]. Neopomacentrus cyanomos is one of the dominant species of coral reef fishes in Taiwan, and distributed in the northeast and southern waters of Taiwan (fishdb.sinca.edu.tw). According to the fishbase of the world [3] listed this species is distributed over the Indo-West Pacific from Red Sea and East Africa to northern Australia and Melanesia (except Fiji), north to southern Japan, Ryukyu Islands, Philippines.

Neopomacentrus cyanomos (Bleeker, 1856) common name is Regal demoiselle, it belong to subfamily Pomacentrinae of family Pomacentridae. 
They dwell in coastal coral reef, are walking a day and small group swimming fish. In our comprehensive review the research in damselfishes, we found that the study of damselfishes is popular. Shao [4] described the species and distribution of Damselfishes in Taiwan, a total number of 16 genera and 89 species of Pomacentridae have been recorded from Taiwan. Jan [5] described the reproduction of neon damselfish Pomacentrus coelestis along the northern coast of Taiwan from an ecological survey. Jan [6] Sympatric spawning of the damselfishes Chromis fumea and Pomacentrus coelestis on the northern coast of Taiwan.

In the past, the research of regal demoiselle was rare. Only Sreeraj and Gopakumar [7] and Setu et al. [8] have described the basal reproductive biology of regal demoiselle. In the present study, we recorded reproductive behaviors and the embryonic developments of regal demoiselle. It will be helpful to understand the biology and ontogenesis of regal demoiselle. This study had been reported as a poster in $7^{\text {th }}$ Indo-Pacific Fish Conference (IPFC) [9] and Conference on Ecophysiology in Marine Organisms.
Center for Marine Bioscience and Biotechnology, NTOU [10].

\section{MATETIALS AND METHODS}

50 individuals of this species were reared in laboratory aquaria to observe reproductive behaviors. The controlled temperature were between $25.2-27.7{ }^{\circ} \mathrm{C}$. Salinity between $32-35$ ppt. We feed them commercial feedstuffs, flesh of fish and shrimp every day. Among reproductive affairs, we took photos and movies for the reproductive behaviors by Nikon Cool-Pix 4500 digital camera and Sony D8 DCR- TRV130 video camera. We tried to siphon out some adhesion demersal eggs (Figure 1) at random, and made use of Olympus CH20 optical microscope and Nikon Cool-Pix 990 digital camera to take down the developments of embryos. We measured length, diameter, length of yolk-sac and maximum length of oil globule etc. of eggs $(n=66)$ (Figure 2), and computed the number of eggs that female fishes spawned at a time. After hatching, we siphoned off the larvae to another aquaria, and fed them with Tetraselmis sp., smallsize rotifer and artemia. 


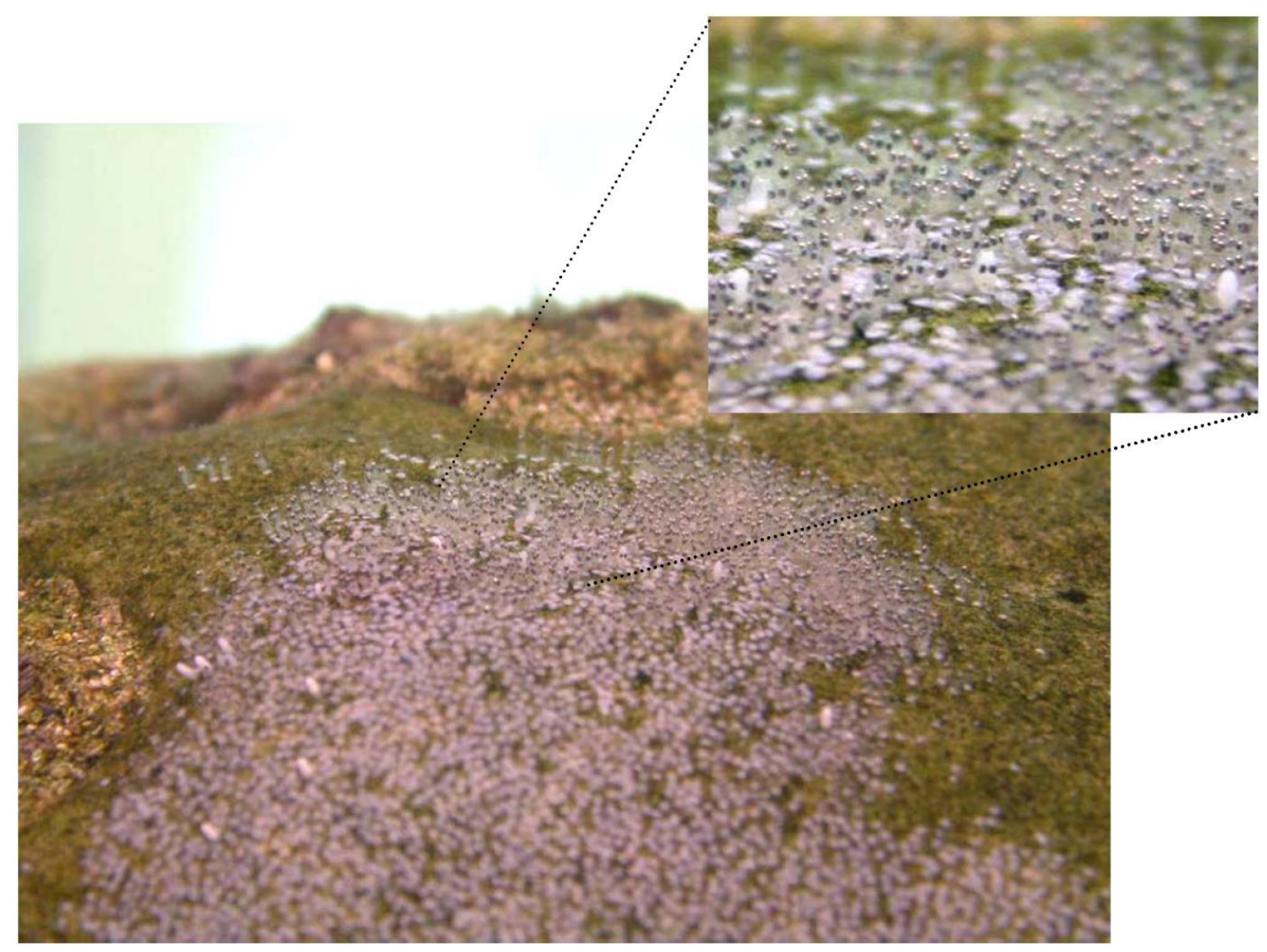

Figure 1. The adhesion developed eggs and their enlarged photo.of $N$. cyanomos

\section{RESULTS}

Regal demoiselle reared in our laboratory aquaria began to lay the eggs from 21 June 2004. After that, they spawned five times at 1, 5, 17, 28 July and 6 August 2004. Among the period, females spawned eggs every 5-13 days ( $8 \pm 4$ days). The male's standard length was longer than the female, respectively $72.2 \pm 5.2 \mathrm{~mm}(\mathrm{n}=5)$ and $61.9 \pm 5.4$ $\mathrm{mm}(\mathrm{n}=13)$.

Reproductive success of the nesting male was quantified by measuring the area of egg patches in each nest during the study period. $N$. cyanomos are polygamy during spawning. In a nest, multiple egg patches which were often deposited by multiple females were frequently found. Thus the larger the egg mass is in a nest demonstrates the more female the nesting male had mated.

\section{Pre-spawning behavior}

In the breeding period, the dominant male had strong territory, selected a suitable spawning substrate and cleaning off a suitable nesting site actively, pecked up the algae, sediment or egg trace on the surface of spawning substrate frequently (Figures 3A). The male may dart up and down as swims forward or twitch while positioning himself perpendicular to his mate's belly. Which stopped until females began to spawn, and tried to woo mature females which lived in the vicinity of him, swam back and forth continually to attract the 
females in coming to his spawning substrate.

Though seemingly bizarre, such actions are normal in pre-spawning rituals. (Figures 3B).

\section{Spawning}

Prior to spawning, the female lowers her ovipositor, a thin egg-delivery tube, about foive millimeter long, white tube extended in front of the female's anal fin during spawning season. The first female entered, male touched female's abdomen with lip at once to stimulate female ovulation. Then, female pressed close her abdomen to the spawning substrates, vibrated body, and lay the translucent eggs slowly. The male and females had a pink convex on their cloaca (Figures 3C). Male's body color changed obviously, his body appeared white stripes from the upper eyes to dorsal and extended from lateral line to the upper anal fin, like a nuptial coloration. The time of spawning occurred on 9 to 12 o'clock at night, and the reproductive behavior continued about three hours. Then she swims a slight distance away and tarries while the male passes over the eggs and fertilizes them. They alternate, laying successive passes of eggs and sperm, for one to three hours. In a reproductive affair, one male could mate with 3-4 females (Figures 3D, E). Females lay about 3210-3560 (n = 3) eggs every times, these eggs were translucent adhesive eggs and were like calabashes.

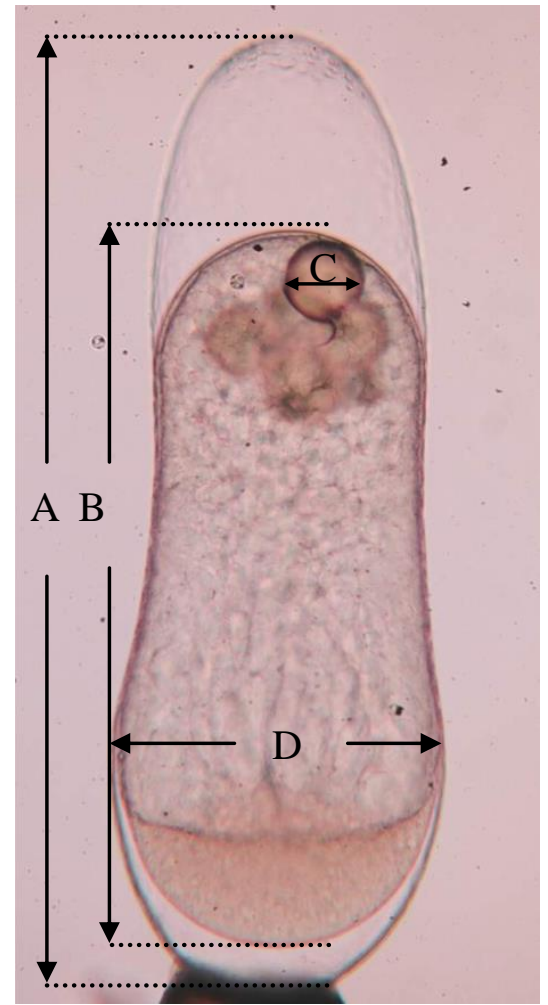

Figure 2. The measurement characters of egg from N. cyanomos (A: length; B: length of yolk-sac; C: maximum length of oil globule; D: diameter) 
Table 1. Embryonic developments of Neopomacentrus cyanomos

\begin{tabular}{|c|c|c|}
\hline $\begin{array}{l}\text { Time after } \\
\text { fertilization } \\
\text { (h) }\end{array}$ & Stage & External features (Figure number) \\
\hline 00:00 & Fertilized egg & $\begin{array}{l}\text { Length: } 1.27 \pm 0.06 \mathrm{~mm} \text {. Diameter: } 0.50 \pm 0.02 \mathrm{~mm} \text {. Length of } \\
\text { yolk- sac: } 0.75 \pm 0.03 \mathrm{~mm} \text {. Oil globule: } 0.17 \pm 0.02 \mathrm{~mm} \text { (Fig. } 4 \mathrm{~A} \text { ) }\end{array}$ \\
\hline 00:20 & 2-cell & First cleavage. (Fig. 4B) \\
\hline 00:40 & 4-cell & Second cleavage. (Fig. 4C; 4D) \\
\hline 01:00 & 8-cell & Third cleavage. (Fig. 4E) \\
\hline $01: 30$ & 16-cell & Fourth cleavage. (Fig. 4F) \\
\hline 02:00 & 32-cell & Fifth cleavage. (Fig. 4G) \\
\hline $02: 30$ & Blastula & Blastcoel became larger. (Fig. 4H) \\
\hline 03:20 & Gastrula & $\begin{array}{l}\text { Invagination occurred at the end of the blastoderm. (Fig. 4I) } \\
\text { Blastoderm covered } 1 / 3,1 / 2,2 / 3,3 / 4 \text { of yolk. (Fig. } 4 \mathrm{~J}-1-4 \mathrm{~J}-4 \text { ) }\end{array}$ \\
\hline $18: 30$ & Blastopore-closing & Blastopore began to close. (Fig. 4K, 4L) \\
\hline $19: 30$ & $\begin{array}{l}\text { Embryonic body } \\
\text { and }\end{array}$ & Embryonic body became clear. Eye vesicle became recognizable. \\
\hline & $\begin{array}{l}\text { eye vesicle } \\
\text { formation }\end{array}$ & 6 somites were visible. (Fig. 4M, 4N, 4O) \\
\hline 33:00 & $\begin{array}{l}\text { Heart pulsation } \\
\text { commencement }\end{array}$ & $\begin{array}{l}\text { Heart beating started. Oil glubules assemble to a big one. } \\
20 \text { somites were recognized. Heart rate: } 87 \pm 7 \text { times/min (Fig. } 4 \mathrm{P})\end{array}$ \\
\hline $35: 00$ & Tail free & $\begin{array}{l}\text { Tail was elevated from yolk. Heart rate: } 173 \pm 4 \text { times/min (Fig. } \\
4 Q \text { ) }\end{array}$ \\
\hline $36: 30$ & Head overturned & $\begin{array}{l}\text { Embryo moved spastically. Head of embryo turned to the top of the } \\
\text { egg. Heart rate: } 192 \pm 8 \text { times/min. (Fig. } 4 \mathrm{R} \text { ) }\end{array}$ \\
\hline 40:00 & Ear vesicle was visible & $\begin{array}{l}\text { Ear vesicle became recognizable. Eye balls were formed. } \\
30 \text { somites were discernible. (Fig. } 4 \text { S) }\end{array}$ \\
\hline 60:00 & Melanocyte heaped & $\begin{array}{l}\text { Melanocyte increased on the body. Head and body grew up. } \\
\text { The end of tail reached yolk. Heart rate: } 221 \pm 5 \text { times/min. (Fig. }\end{array}$ \\
\hline & up on the lip & $4 \mathrm{~T}, 4 \mathrm{U})$ \\
\hline $67: 00$ & $\begin{array}{l}\text { The end of tail } \\
\text { reached eyes }\end{array}$ & $\begin{array}{l}\text { The end of tail reached eyes. The yolk-sac was de-escalating. } \\
\text { Heart rate: } 246 \pm 3 \text { times/min. (Fig. } 4 \mathrm{~V}, 4 \mathrm{~W} \text { ) }\end{array}$ \\
\hline $84: 00$ & $\begin{array}{l}\text { The color of eyes } \\
\text { became dark }\end{array}$ & Embryo moved frequently. Heart rate: $258 \pm 9$ times/min. (Fig. $4 \mathrm{X}$ ) \\
\hline 108:00 & Hatching & $\begin{array}{l}\text { Hatching occurred. Newly-hatched larvae: } 2.85 \pm 0.12 \mathrm{~mm} \\
\text { 30-32 somites. Heart rate: } 262 \pm 5 \text { times/min. (Fig. } 4 \mathrm{Z} \text { ) }\end{array}$ \\
\hline
\end{tabular}

The milk white eggs' length $1.27 \pm 0.06 \mathrm{~mm}(\mathrm{n}=$ 66), diameter $0.50 \pm 0.02 \mathrm{~mm}$, length yolk-sac 0.75 $\pm 0.03 \mathrm{~mm}$, maximum oil globule $0.17 \pm 0.02 \mathrm{~mm}$.

\section{Egg care}

The male breeded the fertilized eggs until they hatched (Figures 3 F).

\section{Egg development}

Through fertilization to hatching, water temperature was controlled between $25.2{ }^{\circ} \mathrm{C}$ and $27.7^{\circ} \mathrm{C}$. The fertilized eggs had one fission every 20 minutes, were disc-like division. The developments of cleavage, morula, gastrula stage, and embryonic body were recorded in Table 1. The morphological changes of embryonic developments in the $N$. cyanomos were showed in Figures $4 \mathbf{A}-\mathbf{Z}$. After fertilized 2.5 hours, these eggs entered blastula stage. After fertilized 3.5 hours, blastoderm began to cover up yolk gradually, it was gastrula stage, and the embryo body was formed in the process. Through 19.5 hours, optic vesicle and auditory vesicle were appeared in succession, and embryo's somites were clear to observe, the number of somites were six. 

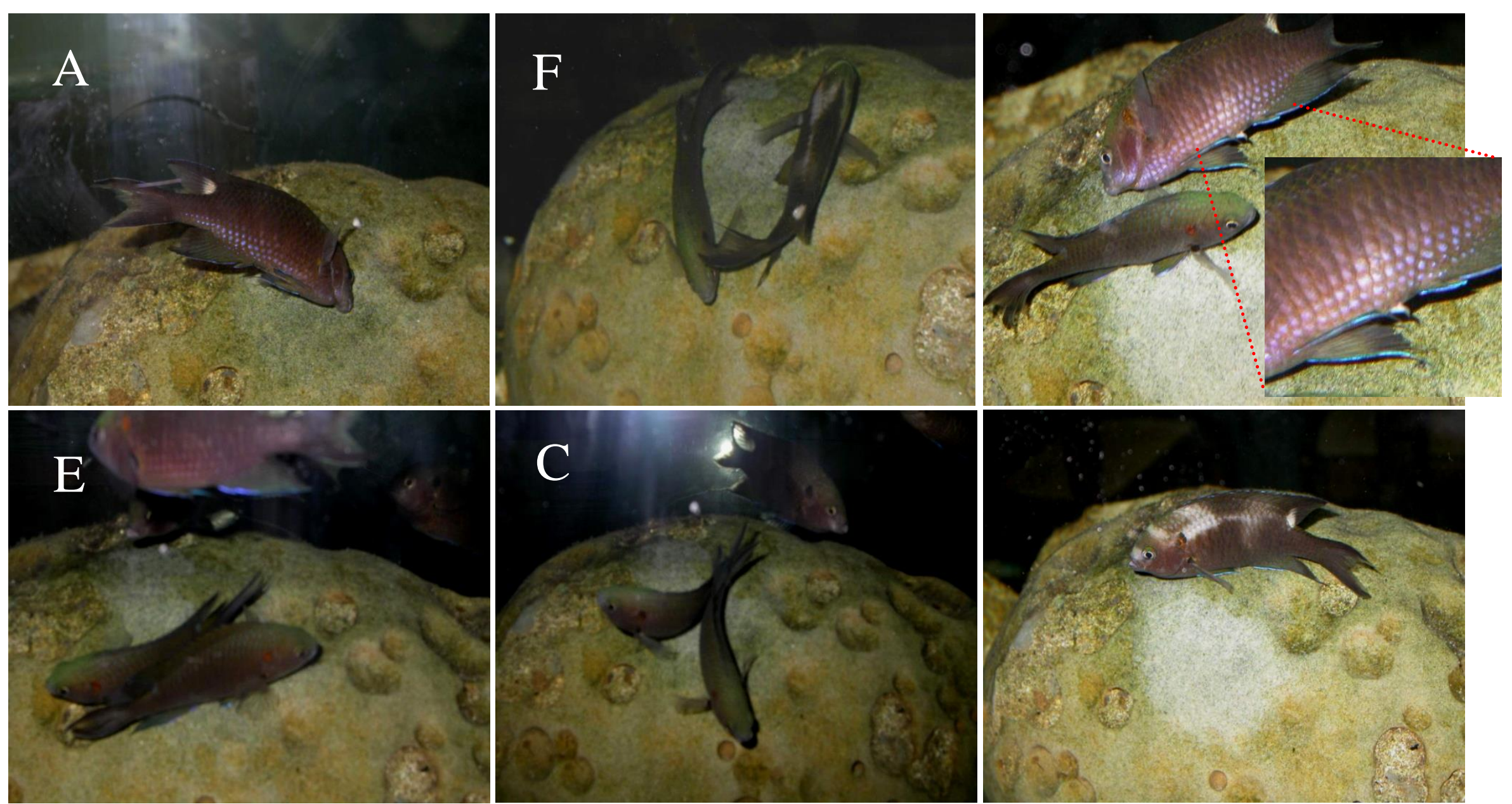

Figures 3. The reprodctive and breeding behaviors of Neopomacentrus cyanomos. A.The male brooder were cleaning the spawning substrate; B. The female spawning, then the male ejaculating; C. The white tube extended in front of the male's anal fin; D. Two females in spawning; E. Two females were spawning together; F. Fertilized eggs were breeded by the male. 

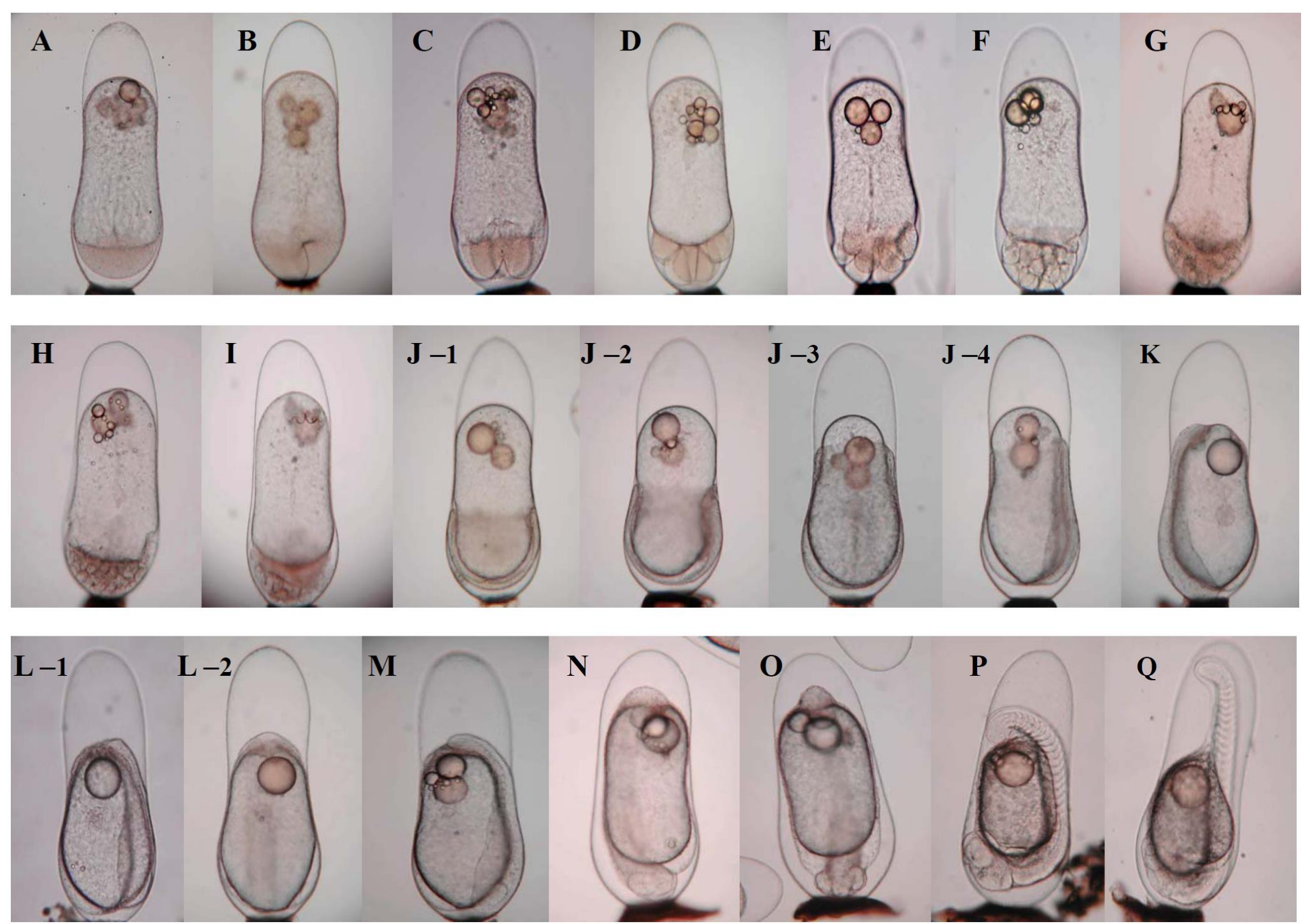

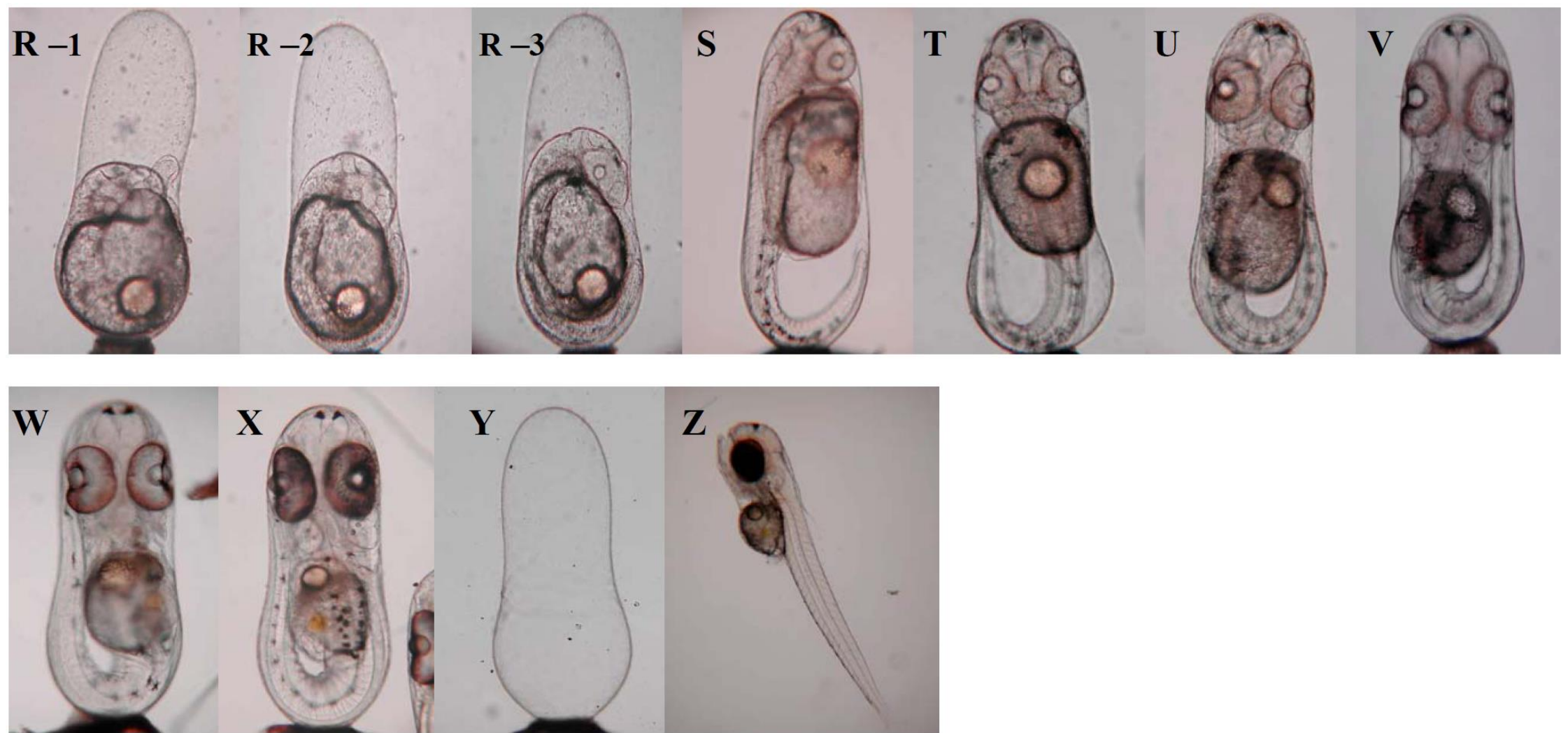

Figures 4. Embryonic development of the Neopomacentrus cyanomos. A. A Fertilization egg; B. 2-cell stage; C. 4-cell stage; D. Proceeding the $3^{\text {rd }}$ cleavage; E. 8-cell stage; F. 16-cell stage; G. 32-cell stage; H. Blastula stage; I. Early stage of gastrula; J. Middle stage of gastrula stage. (1. cover 1/3; 2. cover 1/2; 3. cover 2/3; 4. cover 3/4); K. Later stage of gastrula; L. Blastopore-closing; M. Embryonic body and eye vesicle formation; N. Development of embryonic body (a side view); O. Development of embryonic body (the front of view); P. Heart pulsation commencement; Q. Tail free; R. Overturned; S. Ear vesicle formation; T. Melanocyte heaped up on the lip; U. Body grew up; V. The end of tail reached eyes; W. The yolk sac was de-escalating; X. The color of eyes became dark; Y. The egg shell; Z. Newly-hatched larva. 
After 33 hours, heartbeat appeared and the number of somites increased to 20. Through 35 hours, tail separated from yolk-sac, and 36.5 hours, the head turned over to the top of eggs. The embryo grew up, and the embryo wriggled frequently. After 60 hours the head became big and the body became thick. Until 67 hours, the yolk became to reduce. Through 84 hours, the eyeballs turned black. After 108 hours, larvae broke the eggs and hatched out, body length 2.85 $\pm 0.12 \mathrm{~mm}(\mathrm{n}=10)$, those had good vitality and phototaxist. After hatching, we fed them Tetraselmis sp., small size rotifer and artemia, etc. But, all larvae died after they hatched fifth days later.

\section{DISCUSSION}

On this research, we found that $\mathrm{N}$. cyanomos one dominant male can mate 3-4 famales in a spawning affair, it is similar to the result of Sreeraj and Gopakumar [7]. They observed the gonad state of this species and found the sex ratio is 4.6 in this species.

Egg length of $\mathrm{N}$. cyanomos is smaller than Amphiprion polymnus [11] (1.12- $1.38 \mathrm{~mm}$ vs. 1.85-2.25 mm). Mean hatching time of $\mathrm{N}$. cyanomos is shorter than A. polymnus (108 hr. vs. $172 \mathrm{hr}$.), it might be related to their habits of short duration of egg care.

\section{ACKNOWLEDGMENT}

The authors would like to thank National Taiwan Ocean University (NTOU) for providing research facilities.

\section{REFERENCES}

1. Allen, G. R., (1991). Damselfishes of the World. Mergus Publishers, Melle, Germany. $271 \mathrm{p}$.

2. Allen, G. R., (2000). Pomacentridae (damselfishes). 626-627p. In Randall J. E. and Lim, K. K. P. (eds.) A checklist of the fishes of the South China Sea. The Raffles Bulletin of Zoology Supplement 8: 569-667.

3. Froses, R. and Pauly. D., (2013). Fishbase. World Wide Web electronic publication. www.fishbase.org. Version (12/2013)

4. Shao, Z. T., (1993). Pomacentridae (damselfishes). 414-415p. In Shen S. C. (eds), Fishes of Taiwan. Department of Zoology, National Taiwan University, Taipei.

5. Jan, R. Q., and Ormond, R. F. G. (1992). Spawning of damselfishes on the northern coast of Taiwan, with emphasis on spawning site distribution. Bulletin of the Institute of Zoology Academia Sinica 31: 231-245.

6. Jan, R. Q., (1997). Sympatric spawning of the damselfishes Chromis fumea and Pomacentrus coelestis on the northern coast of Taiwan. Zoological Studies 36: 26-32.

7. Sreeraj, G. and Gopakumar, G., (2004). Reproductive biology of the regal demoiselle Neopomacentrus cyanomos (Bleeker, 1856). Proceedings of the National Seminar on New Frontiers in Marine Bioscience Research 255261p. 
8. Setu, S. K, Ajith Kumar, T. T., Balasubramanian, T., Dabbagh, A. R. and Keshavarz, M., (2010). Breeding and Rearing of Regal Damselfish Neopomacentrus cyanomos (Bleeker, 1856): The Role of Green Water in Larval Survival. World Journal of Fish and Marine Sciences 2 (6): 551-557.

9. Loh, K. H., Cheng, Y. H. and Chen, H. M. (2005). The study of reproductive behaviors and embryonic developments of Neopomacentrus cyanomos. The 7th Indo-Pacific Fish Conference, Taipei, 15-20 May 2005. (Poster P23-02)
10. Loh, K. H., Cheng, Y. H. and Chen, H. M. (2006). The study of reproductive behaviors and embryonic developments of Neopomacentrus cyanomos. Conference on Eco- physiology in Marine Organisms. Center for Marine Bioscience and Biotechnology NTOU, Keelung, 3-4 Oct. 2006. (Poster)

11. Chen C. M., Ho Y. S. and Chen, W. Y., (2003) Breeding Behavior of the Saddleback Anemonefish (Amphiprion polymnus) and its Larval Rearing Study. Journal of Taiwan Fisheries Research $11 \quad(1 \quad \& \quad 2): \quad 29-38$ 